\title{
Rootstock age and grafting season affect graft success and plant growth of papaya (Carica papaya L.) in greenhouse
}

\author{
Van-Hong Nguyen ${ }^{1}$, and Chung-Ruey Yen ${ }^{2 *}$ \\ ${ }^{1}$ National Pingtung University of Science and Technology, Department of Tropical Agriculture and International Cooperation, \\ Pingtung 91201, Taiwan (ROC). \\ ${ }^{2}$ National Pingtung University of Science and Technology, Department of Plant Industry, Pingtung 91201, Taiwan (ROC). \\ *Corresponding author (yencr@mail.npust.edu.tw).
}

Received: 21 August 2017; Accepted: 27 December 2017; doi:10.4067/S0718-58392018000100059

\begin{abstract}
Papaya (Carica papaya L.) is an important fruit crop in many tropical and subtropical countries; it is commercially propagated through seeds, which lead to production of non true-to-type plants. Grafting for mass multiplication of the selected variety is therefore necessary. The objective of this study was to determine the influence of rootstock age and grafting season on the success of cleft grafting and growth of grafted plants under greenhouse conditions. The trial was conducted using an experimental randomized complete block design with $4 \mathrm{~A} \times 2 \mathrm{~B}$ factorial scheme, four blocks, and 15 grafted plants per experimental unit. Factor A represented four rootstock ages (1, 2, 3, and 6 mo) and factor B represented two grafting seasons (summer and autumn). Results showed that rootstock age and grafting season had a significant effect on all the parameters: sprouting time, percentage of graft success, scion sprout length, and number of new leaves per graft. The youngest rootstock age ( $1 \mathrm{mo}$ ) achieved the best results for all the parameters. The best season for grafting was summer. The treatment combination of 1-mo-old rootstocks in summer produced minimum sprouting time $(8.40 \mathrm{~d})$, the highest percentage of graft success $(93.33 \%)$, and graft growth in the greenhouse. Therefore, 1-mo-old rootstocks and grafting in summer or autumn should be used to propagate papaya by cleft grafting.
\end{abstract}

Key words: Carica papaya, propagation, 'Red Lady', young rootstock.

\section{INTRODUCTION}

Papaya (Carica papaya L.) is one of the economically important fruit crops in many tropical and subtropical countries. In 2016, total fruit production was $13050749 \mathrm{t}$ and the total cultivated area 441964 ha (FAOSTAT, 2017). Papaya is a polygamous species with many types of inflorescence. The species has three sex types, which are staminate, pistillate, and hermaphrodite (Dinesh et al., 2001; Paull and Duarte, 2011). Papaya is one of the few fruit crops still being seed-propagated. Seed-propagated papaya seedlings are hindered by problems related to sex reversal, inherent heterozygosity, and the dioecious nature of the crop (Rajeevan and Pandey, 1986; Teixeira et al., 2009). In the commercial production of most producing countries, three or four seedlings are planted at each position; when their sexes are determined, only the hermaphrodites are retained. There are cases in which none of the seedlings are hermaphrodites. In addition, plants are normally seed-propagated, leading to a large variation in fruit production, low and late fruiting, and diminished fruit quality (Allan, 1995; Teixeira et al., 2009). 
The main advantage of vegetative propagation is the certainty of maintaing the mother plant characteristics. The possibility of developing highly productive and disease-resistant materials has been reported; these can be safely spread and keep the characteristics of the papaya mother plants intact through asexual propagation (Sao José and Marin, 1988). The grafted papaya trees bear fruits much lower and earlier, and their dwarf stature provides a longer economic life cycle (Allan, 1995; Chong et al., 2008). In the case of gynodioecious cultivars, bisexual types produce fruits with shape, size, and flavor that are preferred to round fruits from female plants because they obtain a premium price in the market (Teixeira et al., 2009). Asexual propagation makes it is possible to maintain the original parent plant characteristics in addition to several advantages such as higher yield, lower fruiting height, and longer cropping span. Farmers growing papaya in Taiwan support plantlets propagated by the grafting method as compared to plantlets propagated by the cutting method and micropropagation. This is because plantlets propagated by the grafting method have a larger size than plantlets propagated by micropropagation and their roots are stronger than the roots of plantlets propagated by the cutting method.

Papaya grafting propagation has been successfully applied on some cultivars in papaya-growing regions. Several reports of papaya grafting regeneration have been published. Scion shoots from cvs. Co-1 and Honey Dew were successfully cleft-grafted onto uniformly established seedlings (Airi et al., 1986). In Malaysia, some growers use grafting to eliminate female fruiting trees of the cv. Eksotika (Cheah et al., 1993). Chong et al. (2008) reported 80\% success using the cleft grafting method in 'Eksotika' papaya at the nursery stage. A better approach was suggested to obtain a $100 \%$ hermaphrodite stand by cleft grafting papaya seedlings using healthy disease-free scions (Chong et al., 2005). Allan et al. (2010) reported the highest percentage of success (80\%) by side grafting obtained after 15 wk. The variation in results is influenced by different factors. The successful union of scion and stock depend on the proliferation of callus tissue between graft components followed by the union of vascular tissues. This is influenced by factors such as incompatibility, plant species, type of graft, environmental conditions (e.g., temperature and moisture), and rootstock growth activity (Hartmann et al., 2002; Sadhu, 2005). The effect of rootstock age and grafting season on cleft grafting has not yet been reported. In this context, the present study aimed to determine the effect of rootstock age and grafting season on the survival rate and initial growth of 'Red Lady' papaya plants under greenhouse conditions.

\section{MATERIALS AND METHODS}

The study was conducted in 2014-2015 at the National Pingtung University of Science and Technology nursery located in the city of Pingtung, southern Taiwan $\left(22^{\circ} 70^{\prime} \mathrm{N}, 120^{\circ} 55^{\prime} \mathrm{E}\right)$. The monthly mean day length, monthly average, maximum and minimum temperatures, and relative humidity $(\mathrm{RH})$ during the experimental period under greenhouse conditions are presented in Table 1.

\section{Rootstock preparation and Scion preparation}

'Red Lady' seeds were sown in sowing trays. After 20 d, seedlings with two true leaves were transferred to soil pots $(10 \mathrm{~cm} \times 15 \mathrm{~cm})$ with growth medium consisting of peat:soil (1:2) and placed in the nursery as rootstock (Figure 1). Seedling rootstocks were tended in a greenhouse until reaching the grafting age suitable for each experimental treatment. The morphological characteristics of rootstocks at different ages are shown in Table 2.

Table 1. Monthly mean day length, monthly average, maximum and minimum temperatures, and relative humidity during the experimental period (2014-2015) under greenhouse conditions in Pingtung, Taiwan.

\begin{tabular}{lcc}
\hline Meteorological data & Summer & Autumn \\
\hline Day length, $\mathrm{h} \mathrm{d}^{-1}$ & 13.4 & 12.3 \\
Monthly average temperature, ${ }^{\circ} \mathrm{C}$ & 28.6 & 27.5 \\
Monthly mean maximum temperature, ${ }^{\circ} \mathrm{C}$ & 34.4 & 33.5 \\
Monthly mean minimum temperature, ${ }^{\circ} \mathrm{C}$ & 25.2 & 24.8 \\
Relative humidity $(\mathrm{RH}), \%$ & 88.4 & 89.1 \\
\hline
\end{tabular}


Figure 1. Sowing and planting rootstocks in sowing trays (a) and soil pots (b).

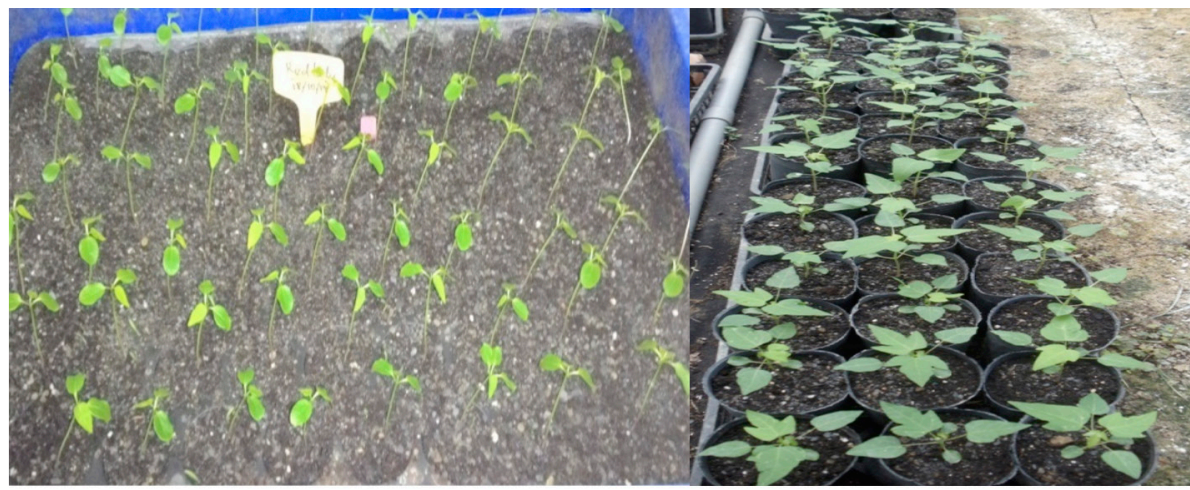

Table 2. Morphological characteristics of rootstocks for different rootstock ages.

\begin{tabular}{|c|c|c|c|}
\hline Rootstock age & Number of leaves & Stem height & Stem diameter \\
\hline 1 month & 13.4 & 44.9 & 6.8 \\
\hline 2 months & 22.0 & 86.6 & 9.1 \\
\hline 3 months & 30.2 & 97.4 & 9.7 \\
\hline 6 months & 36.0 & 100.4 & 10.8 \\
\hline
\end{tabular}

For Scion preparation, Hermaphrodite 'Red Lady' papaya plants were collected as source material to produce scions for this study (Figure 2a). Plants selected to supply scions developed normally and disease-free. Before collecting the scions, mother plants were topped and sprayed with a solution of 6-benzylaminopurine (500 $\left.\mathrm{mg} \mathrm{L}^{-1}\right)$ and gibberellic acid $\left(100 \mathrm{mg} \mathrm{L}^{-1}\right)$ three times at weekly intervals to induce side shoot production (Allan and MacMillan, 1991). After approximately 1 mo, shoots were collected as scions for grafting.

The pest and disease-free scions were selected for softwood grafting. Scion shoots were collected in the morning hours from 07:30 to 09:30 h on the days selected for grafting. The bases of the shoots were kept in water to avoid desiccation.

\section{Execution of the experiment}

The grafting methods used were basically cleft methods (Hartmann et al., 2002; Chong et al., 2008). The base of the 8-mm diameter scion was trimmed to a sharp wedge with a clean, sharp knife. Leaves were trimmed to reduce transpiration loss. The 2-3 cm cuts were trimmed to a smooth surface (Figure 2a). These seedling rootstocks, whose sizes varied linearly between $1 \mathrm{mo}$ and 6 mo of age (Table 2), were topped-off at approximately $10 \mathrm{~cm}$ from the soil

Figure 2. Cleft grafting operation: Hermaphrodite papaya scion (a), rootstock (b), and cleft grafting operation (c).

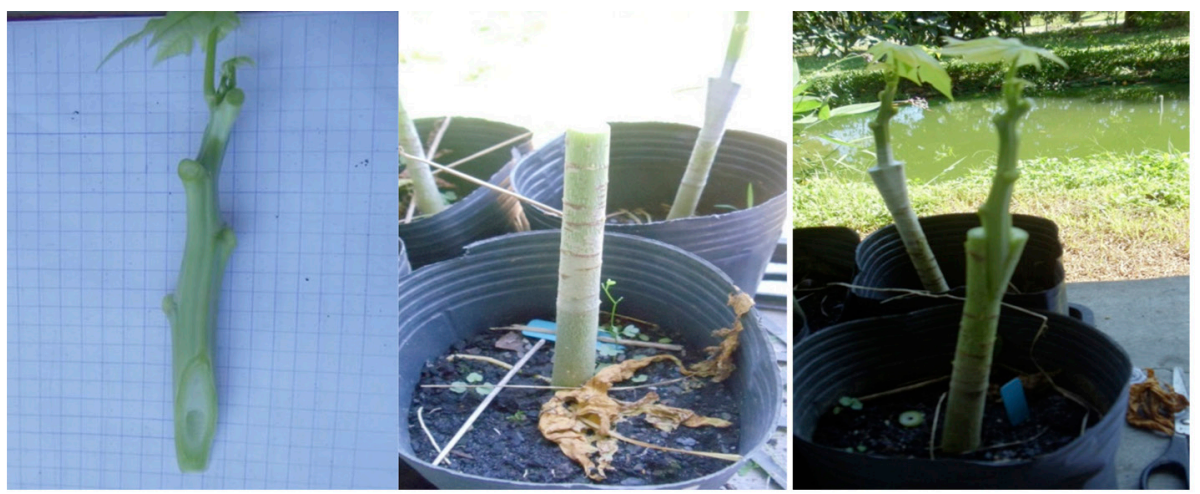


level and an approximate 2-3 cm slit was made at the middle of the stem (Figure 2b). The prepared scions were then inserted into the rootstock so as to ensure that both cambia were aligned; the whole graft was then wrapped firmly with sealing parafilm to ensure good contact (Figure 2c). Parafilm was a suitable wrapping material because of its stretching properties and later breaks down as the plant grows. The grafted plants were covered with a polythene cap to increase the humidity level around the grafted parts. The medium mixture in the pots was adequately watered with a fine rose watering can to maintain more than $80 \% \mathrm{RH}$.

Rootstock age and grafting season are the two experimental factors in this research study. The first factor represented four rootstock ages $(1,2,3$, and $6 \mathrm{mo}$ ). The second factor was two grafting seasons (summer and autumn). Rootstocks collected from uniformly and vigorously growing seedlings of different ages (1, 2, 3, and $6 \mathrm{mo}$ ) were used as rootstocks for softwood grafting. The study was carried out at variable times in summer and autumn under greenhouse conditions in the city of Pingtung, Taiwan. Experiments were analyzed with a randomized complete block design (RCBD) with four replicates, and each replicate included 15 samples per treatment. Data were recorded for the two parameters; the first was sprouting time calculated from the time of grafting to the formation of the grafting union showing the expansion of the first leaves. The second was percentage of graft success estimated at the end of $4 \mathrm{wk}$ and computed by the following formula:

$$
\text { Percentage of graft success }(\%)=\frac{\text { Number of success grafts }}{\text { Total number of grafts done }} \times 100
$$

The variation in scion growth (scion sprout length per graft and number of new leaves per graft) was recorded every week to determine the rate of initial growth of papaya plantlets in the greenhouse. The collected data were statistically analyzed to find the significant difference between treatments. Statistical analyses were performed with SAS 9.0 software (SAS Institute, Cary, North Carolina, USA), and means were compared by Duncan's new multiple range test.

\section{RESULTS}

The effect of different grafting seasons and rootstock ages on the success of cleft grafting (sprouting time and percentage of graft success) and growth of grafted plants (scion sprout length and number of new leaves) was significant (Table 3). The summary of the ANOVA shows the interaction between the grafting season and rootstock age factors for the parameters.

\section{Effect of different rootstock ages}

The effect of rootstock age on the studied parameters was significant at the 0.01 probability level (Table 4). Grafting a 1-mo-old rootstock gave the best results as compared to grafting on 2-, 3-, and 6-mo-old rootstocks $(\mathrm{P}<0.01)$. The shortest sprouting time $(8.45 \mathrm{~d})$ took place in grafts with 1-mo-old rootstocks. The longest sprouting time (14.67 d) occurred in grafts with 6-mo-old rootstocks. Sprouting time $(9.71 \mathrm{~d})$ was recorded with 2-mo-old rootstocks followed by 3-mo-old rootstocks. The percentage of graft success was significantly affected by rootstock age. The highest graft success $(90.83 \%)$ was recorded in 1-mo-old rootstocks, which was significantly similar to the graft

Table 3. ANOVA for grafting season and rootstock age in papaya cleft grafting.

\begin{tabular}{lrcccc}
\hline & & \multicolumn{4}{c}{ Mean square } \\
\cline { 3 - 6 } Variation factor & DF & $\begin{array}{c}\text { Sprouting } \\
\text { time }\end{array}$ & $\begin{array}{c}\text { Percentage of } \\
\text { graft success }\end{array}$ & $\begin{array}{c}\text { Scion sprout } \\
\text { length }\end{array}$ & $\begin{array}{c}\text { Number of } \\
\text { leaves }\end{array}$ \\
\hline Grafting season (S) & 1 & $1.68^{* *}$ & $800.00^{* *}$ & $0.36^{* *}$ & $0.10^{* *}$ \\
Rootstock age (A) & 3 & $61.95^{* *}$ & $3616.83^{* *}$ & $10.67^{* *}$ & $3.71^{* *}$ \\
$\mathrm{~S} \times \mathrm{A}$ & 3 & $0.16^{*}$ & $92.60^{* *}$ & $0.10^{* *}$ & $0.02^{* *}$ \\
Error & 21 & 0.05 & 27.77 & 0.02 & 0.003 \\
CV, \% & & 1.98 & 7.48 & 5.38 & 2.23 \\
\hline
\end{tabular}

*,** Significant at the 0.05 and 0.01 probability levels, respectively.

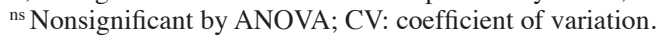


Table 4. Effect of rootstock age on the success of cleft grafting and growth of grafted plants.

\begin{tabular}{lcccc}
\hline & & \multicolumn{3}{c}{4 weeks after grafting } \\
\cline { 3 - 5 } Rootstock age & $\begin{array}{c}\text { Sprouting } \\
\text { time }\end{array}$ & $\begin{array}{c}\text { Percentage of } \\
\text { graft success }\end{array}$ & $\begin{array}{c}\text { Scion sprout } \\
\text { length }\end{array}$ & $\begin{array}{c}\text { Number of } \\
\text { new leaves }\end{array}$ \\
\hline \multirow{2}{1}{ month } & $\mathrm{d}$ & $\%$ & $\mathrm{~cm}$ & \\
2 months & $8.45 \mathrm{a}$ & $90.83 \mathrm{a}$ & $3.70 \mathrm{a}$ & $3.09 \mathrm{a}$ \\
3 months & $9.71 \mathrm{~b}$ & $83.33 \mathrm{~b}$ & $3.01 \mathrm{~b}$ & $2.69 \mathrm{~b}$ \\
6 months & $12.42 \mathrm{c}$ & $64.17 \mathrm{c}$ & $2.14 \mathrm{c}$ & $2.24 \mathrm{c}$ \\
\hline
\end{tabular}

The same letters for means in the same column indicate nonsignificant differences according to Duncan test $(\mathrm{P}<0.01)$.

with 2-mo-old rootstocks. It was followed by 3-mo-old-rootstocks. The lowest percentage of success (43.33\%) was observed in 6-mo-old rootstocks.

The growth of grafted plants was significantly affected by rootstock age $(\mathrm{P}<0.01)$. The highest sprout length $(3.70 \mathrm{~cm})$ was recorded in 1-mo-old rootstocks followed by 2- and 3-mo-old rootstocks. It was the lowest in 6-moold rootstocks. Significant values were found in the number of new leaves per graft at different rootstock ages. The maximum number of new leaves (3.09 leaves) was found in 1-mo-old rootstocks and the minimum (1.50 leaves) in 6-mo-old rootstocks. The lowest number of new leaves was reached at other rootstock ages (2 or 3 mo) (Table 4).

\section{Effect of different grafting seasons}

The effect of grafting seasons on the success of cleft grafting and growth of grafted plants was significant at a 0.01 probability level. Summer grafts gave the best results as compared to autumn grafts for the following variables: sprouting time, percentage of graft success, scion sprout length, and number of new leaves per graft (Table 5).

\section{Effect of interaction between rootstock age and grafting season}

The interaction between rootstock age and grafting season on sprouting time was significant at a 0.01 probability level. The minimum sprouting time $(8.40 \mathrm{~d})$ took place in the 1-mo-old rootstock and summer interaction, which was significantly similar to the grafts of 1-mo-old rootstock in autumn $(8.51 \mathrm{~d})$. The longer sprouting time was shown in the interaction of 2-, 3-, and 6-mo-old rootstocks and summer or in the combination of 2- and 3-moold rootstocks and autumn. As for statistical significance, the maximum sprouting time (15.02 d) was the 6-moold rootstock and autumn interaction. There was a significant effect of the interaction between rootstock age and grafting season on the graft success rate $(\mathrm{P}<0.01)$. The highest percentage of graft success was achieved in summer with 1-mo-old rootstocks, which was significantly similar to the grafts of 2-mo-old rootstocks in summer or the grafts of 1-mo-old rootstocks in autumn (Table 6). The lowest results were in the summer and autumn interactions with 2- and 3-mo-old rootstocks. The lowest percentage of graft success (33.33\%) was in the autumn and 6-mo-age rootstock interaction.

The growth of grafted plants was a significant combined effect of rootstock age and grafting season on scion height after successful grafting $(\mathrm{P}<0.01$, Table 6$)$. The highest scion sprout length $(3.74 \mathrm{~cm})$ was obtained in the 1-mo-old rootstock and summer interaction, which was significantly similar to the graft of 1-mo-old rootstocks in autumn. The lowest scion sprout length was in the interactions between 6-mo-old rootstocks and summer $(1.04 \mathrm{~cm})$

Table 5. Effect of grafting season on the success of cleft grafting and growth of grafted plants.

\begin{tabular}{lcccc}
\hline & & \multicolumn{3}{c}{ 4 weeks after grafting } \\
\cline { 3 - 5 } Rootstock age & $\begin{array}{c}\text { Sprouting } \\
\text { time }\end{array}$ & $\begin{array}{c}\text { Percentage of } \\
\text { graft success }\end{array}$ & $\begin{array}{c}\text { Scion sprout } \\
\text { length }\end{array}$ & $\begin{array}{c}\text { Number of } \\
\text { new leaves }\end{array}$ \\
\hline Summer & $\mathrm{d}$ & $\%$ & $\mathrm{~cm}$ & \\
Autumn & $11.08 \mathrm{a}$ & $75.42 \mathrm{a}$ & $2.58 \mathrm{a}$ & $2.44 \mathrm{a}$ \\
\hline
\end{tabular}

The same letters for means in the same column indicate nonsignificant differences according to Duncan test $(\mathrm{P}<0.01)$. 
Table 6. Effect of interaction between rootstock age and grafting season on the success of cleft grafting in papaya.

\begin{tabular}{lccccc}
\hline \multirow{2}{*}{$\begin{array}{l}\text { Grafting } \\
\text { season }\end{array}$} & $\begin{array}{c}\text { Rootstock } \\
\text { age }\end{array}$ & $\begin{array}{c}\text { Sprouting } \\
\text { time }\end{array}$ & $\begin{array}{c}\text { Percentage of } \\
\text { graft success }\end{array}$ & $\begin{array}{c}\text { Scion sprout } \\
\text { length }\end{array}$ & $\begin{array}{c}\text { Number of } \\
\text { new leaves }\end{array}$ \\
\hline \multirow{3}{*}{ Summer } & mo & $\mathrm{d}$ & $\%$ & $\mathrm{~cm}$ & \\
& 1 & $8.40 \mathrm{a}$ & $93.33 \mathrm{a}$ & $3.74 \mathrm{a}$ & $3.13 \mathrm{a}$ \\
& 2 & $9.54 \mathrm{~b}$ & $86.67 \mathrm{ab}$ & $3.14 \mathrm{~b}$ & $2.75 \mathrm{~b}$ \\
\multirow{4}{*}{ Autumn } & 3 & $12.08 \mathrm{~d}$ & $68.34 \mathrm{c}$ & $2.39 \mathrm{c}$ & $2.37 \mathrm{~d}$ \\
& 6 & $14.31 \mathrm{f}$ & $53.33 \mathrm{~d}$ & $1.04 \mathrm{e}$ & $1.50 \mathrm{f}$ \\
& 1 & $8.51 \mathrm{a}$ & $88.34 \mathrm{a}$ & $3.67 \mathrm{a}$ & $3.06 \mathrm{a}$ \\
& 2 & $9.88 \mathrm{c}$ & $80.00 \mathrm{~b}$ & $2.88 \mathrm{~b}$ & $2.63 \mathrm{c}$ \\
& 3 & $12.75 \mathrm{e}$ & $60.00 \mathrm{~d}$ & $1.89 \mathrm{~d}$ & $2.12 \mathrm{e}$ \\
& 6 & $15.02 \mathrm{~g}$ & $33.33 \mathrm{e}$ & $1.02 \mathrm{e}$ & $1.50 \mathrm{f}$ \\
\hline
\end{tabular}

The same letters for means in the same column indicate nonsignificant differences according to Duncan test $(\mathrm{P}<0.01)$.

or autumn $(1.02 \mathrm{~cm})$. The medial results were recorded for grafts of 2- and 3-mo-old rootstocks in summer or 2- and 3-mo-old rootstocks in autumn. The number of new leaves per graft was expressed with a high degree of dispersion and ranged between 3.13 and 1.5 leaves. The maximum number of new leaves was found in 1-mo-old rootstocks grafted in summer (3.13 leaves) or autumn (3.06 leaves). The lowest results were obtained in the interaction between older rootstocks in both summer and autumn. The lowest number of leaves was in the combinations of 6-mo-old rootstocks and summer (1.57 leaves) or autumn (1.51 leaves).

The variation of scion height describes the weekly rate of plantlet height growth in summer and autumn and is shown in Figure 3. In both grafting seasons, scion height growth in younger rootstocks was higher at different times (wk) after grafting, and needed a shorter time to reach a stable scion height growth rate than the older rootstocks. Scion growth in 1-mo-old rootstocks was the highest, followed by 2-mo-old rootstocks; it was the lowest in 6-moold rootstocks. The 1-mo-old rootstocks took the shortest time (after $2 \mathrm{wk}$ ) to achieve a stable growth rate compared to the others. In terms of grafting season, scion growth in summer tended to be higher than in autumn.

The variation in the number of leaves at different times (wk) after grafting in summer and autumn are shown in Figure 4. It was found that the variation in the number of leaves has a similar trend as the variation of the scion height parameter (Figure 3). In both grafting seasons and in younger rootstock, the increase in the number of leaves on the scion was faster and took a shorter time to reach a stable leaf formation rate than older rootstocks. The number of new leaves in each week in 1-mo-old rootstocks was the highest, followed by 2-mo-old rootstocks, and it was the lowest in 6-mo-old rootstocks. It took the shortest time (after $2 \mathrm{wk}$ ) for 1-mo-old rootstocks to reach a stable leaf formation rate as compared to the others. In terms of grafting season, the leaf formation rate in summer tended to be higher than in autumn.

Figure 3. Variation of scion height growth at different times (weeks) after grafting.

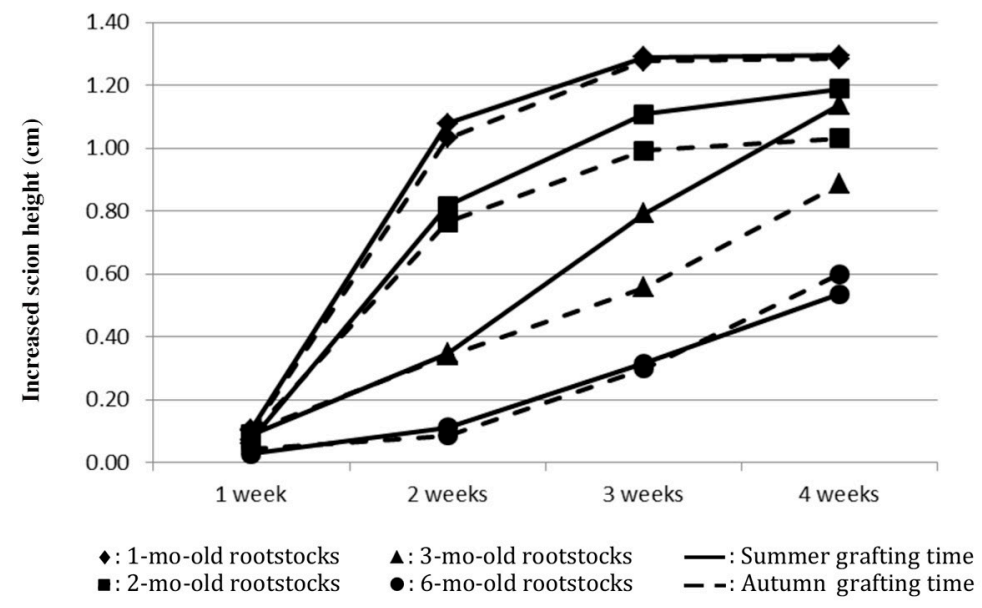


Figure 4. Variation in number of leaves at different times (weeks) after grafting.

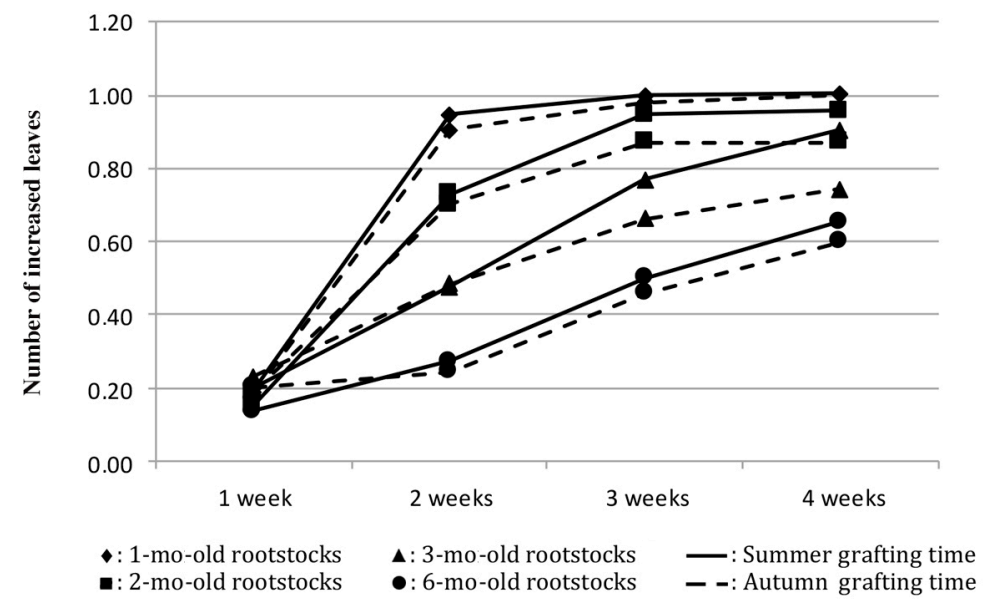

\section{DISCUSSION}

Rootstock age and grafting season are factors that affect grafting success (Hartmann et al., 2002; Kumar, 2011). In former papaya research studies, the effects of rootstock age and grafting seasons on grafting have not been studied and reported. On the other hand, several reports of the effects of these factors on grafting in mango, jackfruit, and cashew have been published (Islam et al., 2004; Mahunu et al., 2009; Mandal et al., 2011).

\section{Effect of rootstock age on cleft grafting and growth of papaya plantlets}

The present study has stated that younger rootstocks require minimum sprouting time when testing rootstock age $(1,2,3$, and 6 mo). This concurred with research about cashew grafting by Mahunu et al. (2009), mango grafting by Alam et al. (2006) and Upadhya et al. (2014). Chong et al. (2008) achieved the highest rate of graft success when grafting 'Eksotika' papaya with 2-mo-old rootstocks. Results have also shown that younger rather than old rootstocks obtained a higher percentage of graft success; the highest rate occurred when grafted with 1-mo-old rootstocks. This coincides with Islam et al. (2004) working in mango and Dadzie et al. (2014) working in kola. Using young rootstocks gave the best results for scion height and number of leaves. This was also found by Reddy (1986), who reported that the highest scion height and maximum number of leaves was on a graft prepared with 3-mo-old rootstocks in mango.

Rootstock age is related to the regenerating ability of a plant part, which is found in younger rootstocks. This is because of higher meristematic cell activity resulting in faster callus formation and quick healing of the grafting union. In general, the lowest graft union success could be attributed to the lack of intimate contact of the cambial region of both stock and scion and interference of latex exudation (Hartmann et al., 2002). It was reported that the rapid formation of callus (parenchymatous) tissues allowing the translocation of vital biochemical compounds of stock and scion might be the reason for the minimum number of days for graft union (Kilany et al., 2012). Another reason for scion growth after the graft was because younger stocks store more carbohydrates and other food substances, and this leads to more vegetative growth (Zimmerman, 1958). Additionally, translocation of vital biochemical compounds of stock and scion might be the reason for increasing scion height and number of leaves per graft in younger rather than old rootstocks. Older trees accumulate high latex and phenolic exudation that may reduce the growth rate of grafted plants. On the other hand, scions from younger trees are said to have a higher concentration of meristems that increase plant juvenility and enhance faster growth.

\section{Effect of grafting season on cleft grafting and growth of papaya plantlets}

Several research studies have reported that environmental conditions directly affect graft union success. Temperature and humidity are two important factors that greatly influence graft union healing by callus formation (Hartmann et 
al., 2002; Sadhu, 2005). In the present study, the results in summer were better than in autumn for the time required for graft take, percentage of graft take, scion sprout length, and number of new leaves per graft parameters. This could first be explained as the rate of graft union linearly increasing between 5 and $32{ }^{\circ} \mathrm{C}$ (Sadhu, 2005). In the present study, the daily mean temperature in summer $\left(28.6^{\circ} \mathrm{C}\right)$ was higher than in autumn $\left(27.5^{\circ} \mathrm{C}\right)$. It is therefore true that temperature in summer is a cause to obtaining better results as compared to autumn. Secondly, maintaining high humidity is very important to prevent the scion from drying (Sadhu, 2005). The difference in humidity between summer $(88.4 \%)$ and autumn $(89.1 \%)$ may not be large enough to make a difference in scion desiccation after grafting. Meanwhile, light affects callus formation and plant photosynthesis (Hartmann et al., 2002; McMahon et al., 2007; Afshari et al., 2011; Köse, 2014). The month of May has longer days that provide more light energy for photosynthesis and nutrient accumulation to promote graft union formation and scion growth after grafting as compared to September. This may be reason why faster graft union success and stronger growth of grafted plantlets occur in May. The results agree with Islam et al. (2004), who reported that the best mango grafting results (days required for success and percentage of survival) were observed on 16 May in Bangladesh.

\section{Combined effect of rootstock age and grafting season on cleft grafting and growth of papaya plantlets}

Results showed that the combination of rootstock age and different seasonal environment led to different results in the papaya graft. Results of the interaction between rootstock age and grafting season explained that the combination of 1-mo-old rootstocks and summer achieved the best result for all parameters. The percentage of graft take achieved was higher than the previous results mentioned by Chong et al. (2008), who reported that the percentage of success was $80 \%$ in cleft grafting on 'Eksotika' papaya, and Allan et al. (2010), who obtained an $80 \%$ percentage of success by side grafting after $15 \mathrm{wk}$. Additionally, the results of initial growth of papaya plantlets after grafting with 1-moold rootstocks in summer are satisfactory for producing commercial plantlets. The differentiation may be due to a variety of factors and experimental conditions. The outstanding results achieved in the present research study were the responsibility of 1-mo-old rootstocks with environmental conditions that might be the most favorable for the rate of callus formation and graft union healing.

\section{CONCLUSIONS}

Propagation of 'Red Lady' papaya through cleft grafting is affected by grafting season and rootstock age. Among tested rootstock ages, the 1-mo-old rootstocks achieved the best grafting success. Summer is more suitable than autumn for cleft grafting in papaya. The results showed that grafting 'Red Lady' papaya with 1-mo old rootstocks in both summer and autumn gave the best results for sprouting time, percentage of graft success, scion sprout length, and number of new leaves. The results should be applied to produce and supply a large number of plantlets for farming in Taiwan or in tropical areas with a similar climate.

\section{ACKNOWLEDGEMENTS}

We thank the National Pingtung University of Science and Technology for the financial support to carry out the experiment and to Mr. Shang-Han Tsai for his support in conducting the field work.

\section{REFERENCES}

Afshari, R.T., Angoshtari, R., and Kalantari. S. 2011. Effect of light and different plant growth regulators on inductions of callus growth in repeseed (Brassica napus) genotype. Journal of Plant Molecular Biology and Omics 4:60-67.

Airi, S.K., Gill, S.S., and Singh, S.N. 1986. Clonal propagation of papaya (Carica papaya L.) Journal of Agriculture Research, Punjab 23:237-239.

Alam, M.A., Islam, M.S., Uddin, M.Z., Barman, J.C., and Quamruzzaman, A.K.M. 2006. Effect of age of seedling and variety of scionin stone grafting of mango. International Journal of Sustainable Crop Production 1(2):27-32.

Allan, P. 1995. Propogation of 'Honey Gold' papayas by cuttings. Acta Horticulturae 370:99-102. doi:10.17660/ ActaHortic.1995.370.15. 
Allan, P., Clark, C., and Laing, M. 2010. Grafting papayas (Carica papaya L.) Acta Horticulturae 851:253-258. doi:10.17660/ActaHortic.2010.851.38.

Allan, P., and MacMillan, C.N. 1991. Advances in propagation of Carica papaya L. cv. Honey Gold cuttings. Journal of the Southern African Society for Horticultural Sciences 1(2):69-72.

Cheah, L.S., Yau, K.K., Subramaniam, S., and Lai, F.T. 1993. Cleft grafting and quality improvements of papaya cv. Eksotika. Malaysian Agricultural Research and Development Institute (MARDI), Johor Bahru, Malaysia.

Chong, S.T., Prabhakaran, R., and Lee, H.K. 2008. An improved technique of propagating 'Eksotika' papaya. Acta Horticulturae 787:273-276. doi:10.17660/ActaHortic.2008.787.30.

Chong, S.T., Raveendranathan, P., and Lee, H.K. 2005. Improving performance and uniformity of 'Eksotika' papaya through cleft grafting. In 1st International Symposium on Papaya, Genting Highlands. 22-24 November 2005. International Society for Horticultural Science (ISHS), Leuven, Belgium.

Dadzie, A.M., Akpertey, A., Yeboah, J., Opoku, S.Y., Ofori, A., Lowor, S., et al. 2014. Genotypic effect of rootstock and scion on grafting success and growth of kola (Cola nitida) seedlings. American Journal of Plant Sciences 5(26):3873-3879.

Dinesh, M.R., Reddy, B.M.C., and Reena, N.A. 2001. Varietal improvement of papaya (Carica papaya L.) Journal of Applied Horticulture 2:121-123.

FAOSTAT. 2017. Statistics division. Production/Crops. Food and Agriculture Organization of the United Nations, Rome, Italy. Available at http://www.fao.org/faostat/en/\#data/QC (accessed 19 December 2017).

Hartmann, H.T., Kester, D.E., Davies, F.T., and Geneve, R.L. 2002. Hartmann and Kester's plant propagation: Principles and practices. $8^{\text {th }}$ ed. Prentice Hall, Upper Saddle River, New Jersey, USA.

Islam, M.N., Rahim, M.A., Naher, M.N.A., Azad, M.I., and Shafjahan, M. 2004. Effect of time of operation and age of rootstock on the success of inserted contact grafting in mango. Asian Journal of Plant Science 3(5):636-641. doi:10.3923/ajps.2004.636.641.

Kilany, O.A., Abd El-Zaher, M.H., and Hamed, H.H. 2012. The relationship between the histological features in the grafting areas and the compatibility degrees of some mango cultivars onto nucellar seedlings. Journal of Horticultural Science and Ornamental Plants 4(1):58-65.

Köse, B. 2014. Effect of light intensity and temperature on growth and quality parameters of grafted vines. Notulae Botanicae Horti Agrobotanici Cluj-Napoca 42(2):507-515. doi:10.15835/nbha.42.2.9704.

Kumar, G.N.M. 2011. Propagation of plants by grafting and budding. A Pacific Northwest Extension Publication, Pullman, Washington, USA.

Mahunu, G.K., Adjei, P.Y., and Asante, A.K. 2009. Comparative studies on ages of rootstock seedlings and graft methods in cashew (Anacardium occidentale L.) Ghana Journal of Horticulture 7:11-17.

Mandal, J., Mandal, B.K., Singh, R.R., and Jaiswal, U.S. 2011. Effect of age of rootstock, grafting time and varieties on the success of soft wood grafting in mango. The Asian Journal of Horticulture 6(2):412-417.

McMahon, M.J., Kofranek, A.M., and Rubatzky, V.E. 2007. Hartmann's plant science: Growth, development, and utilization of cultivated plant. $4^{\text {th }}$ ed. Prentice Hall, Upper Saddle River, New Jersey, USA.

Paull, R.E., and Duarte, O. 2011. Tropical fruits. Crop Production Science in Horticulture Book 20. 436 p. CABI, London, UK.

Rajeevan, M.S., and Pandey, R.M. 1986. Lateral bud culture of papaya (Carica papaya L.) for clonal propagation. Plant Cell, Tissue and Organ Culture 6:181-188. doi:10.1007/BF00180803.

Reddy, C.V. 1986. Effect of age of the rootstock and scion length on success of softwood grafting in mango. Indian Journal of Horticulture 67:123-126.

Sadhu, M.K. 2005. Plant propagation. New Age Internationa Ltd., New Delhi, India.

Sao José, A.R., e Marin, S.L.D. 1988. Propagação do mamoeiro. p. 177-196. In Ruggiero, C. (ed.) Mamão. FUNEP, Jaboticabal, São Paulo, Brasil.

Teixeira, J.A., Rashid, Z., Nhut, D.T., Dharini, S., Abed, G., Manoel, T.S.J., et al. 2009. Papaya (Carica papaya L.) biology and biotechnology. Tree and Forestry Science and Biotechnology 1(1):47-73.

Upadhya, B., Baral, D.B., Gautam, D.M., and Shrestha, S.M. 2014. Influence of rootstock age and pre-defoliation of scion on the success of epicotyl grafting of mango. International Journal of Research 1(7):172-182.

Zimmerman, M.M. 1958. Translocation of organic substances in the phloem of trees. The physiology of forest trees. Ronald Press, New York, USA. 